\title{
Carbonate Hydroxyapatite and Silicon-Substituted Carbonate Hydroxyapatite: Synthesis, Mechanical Properties, and Solubility Evaluations
}

\author{
L. T. Bang, ${ }^{1}$ B. D. Long, ${ }^{2}$ and R. Othman ${ }^{1}$ \\ ${ }^{1}$ Rekagraf Laboratory, School of Materials and Mineral Resources Engineering, Universiti Sains Malaysia, \\ 14300 Nibong Tebal, Malaysia \\ ${ }^{2}$ Department of Mechanical Engineering, Faculty of Engineering, University of Malaya, 50603 Kuala Lumpur, Malaysia
}

Correspondence should be addressed to R. Othman; radzali@eng.usm.my

Received 13 December 2013; Accepted 18 January 2014; Published 2 March 2014

Academic Editors: F. Cleymand and E. Sahmetlioglu

Copyright (C) 2014 L. T. Bang et al. This is an open access article distributed under the Creative Commons Attribution License, which permits unrestricted use, distribution, and reproduction in any medium, provided the original work is properly cited.

\begin{abstract}
The present study investigates the chemical composition, solubility, and physical and mechanical properties of carbonate hydroxyapatite $\left(\mathrm{CO}_{3} \mathrm{Ap}\right)$ and silicon-substituted carbonate hydroxyapatite $\left(\mathrm{Si}-\mathrm{CO}_{3} \mathrm{Ap}\right)$ which have been prepared by a simple precipitation method. X-ray diffraction (XRD), Fourier transform infrared spectroscopy (FTIR), X-ray fluorescence (XRF) spectroscopy, and inductively coupled plasma (ICP) techniques were used to characterize the formation of $\mathrm{CO}_{3} \mathrm{Ap}$ and $\mathrm{Si}-\mathrm{CO}_{3} \mathrm{Ap}$. The results revealed that the silicate $\left(\mathrm{SiO}_{4}{ }^{4-}\right)$ and carbonate $\left(\mathrm{CO}_{3}{ }^{2-}\right)$ ions competed to occupy the phosphate $\left(\mathrm{PO}_{4}{ }^{3-}\right)$ site and also entered simultaneously into the hydroxyapatite structure. The $\mathrm{Si}$-substituted $\mathrm{CO}_{3}$ Ap reduced the powder crystallinity and promoted ion release which resulted in a better solubility compared to that of $\mathrm{Si}$-free $\mathrm{CO}_{3} \mathrm{Ap}$. The mean particle size of $\mathrm{Si}-\mathrm{CO}_{3} \mathrm{Ap}$ was much finer than that of $\mathrm{CO}_{3} \mathrm{Ap}$. At $750^{\circ} \mathrm{C}$ heat-treatment temperature, the diametral tensile strengths (DTS) of Si-CO $\mathrm{CO}_{3} \mathrm{Ap}_{\mathrm{C}} \mathrm{CO}_{3} \mathrm{Ap}$ were about $10.8 \pm 0.3$ and $11.8 \pm 0.4 \mathrm{MPa}$, respectively.
\end{abstract}

\section{Introduction}

The use of hydroxyapatite (HA) as bone substitute is well known for its bioactivity and osteoconductivity in vivo [1, 2]. However, the natural bone which differs from pure HA contains about $4-8 \mathrm{wt} \%$ carbonate along with several multisubstituted ions $\left(\mathrm{Na}^{+}, \mathrm{Mg}^{2+}, \mathrm{K}^{+}, \mathrm{F}^{-}, \mathrm{Cl}^{-}\right.$, etc. $)$in its structure [3-5]. Carbonate substituted into the HA structure $\left(\mathrm{CO}_{3} \mathrm{Ap}\right)$ is of special interest because the $\mathrm{CO}_{3}{ }^{2-}$ ion has an impact on different pathologies of human tissues, such as dental caries [6]. $\mathrm{CO}_{3} \mathrm{Ap}$ was also reported to be more soluble in vivo than HA and to increase the local concentration of calcium and phosphate ions that are necessary for new bone formation [7]. Moreover, $\mathrm{CO}_{3} \mathrm{Ap}$ is resorbed faster by osteoclasts and replaced with the new bone at a higher rate compared to HA [8]. $\mathrm{CO}_{3}{ }^{2-}$ ion can replace $\mathrm{OH}^{-}$or $\mathrm{PO}_{4}{ }^{3-}$ ions giving $\mathrm{A}$ - or $\mathrm{B}$-type $\mathrm{CO}_{3} \mathrm{Ap}$, respectively. If these substitutions take place simultaneously, an AB-type substitution occurs, as in the case of the bone mineral $[7,9]$.
It was reported that $\mathrm{Si}$ enhances and stimulates osteoblast-like cell activity [10] in vitro and induces a higher dissolution rate in vivo [11]. The solubility was observed to increase with a decrease in structural order due to the presence of the foreign ions (i.e., $\mathrm{CO}_{3}{ }^{2-}, \mathrm{SiO}_{4}{ }^{4-}$ ) in the HA structure [12]; nonetheless, only few papers have investigated ion release in synthetic fluids [11, 13]. Therefore, the development of synthetic HA powders with a fully completed ionic substitution in the HA lattice is of great importance in order to mimic that of the natural bone.

Numerous research works have focused on the synthesis of HA biomaterial substituted with single- or multi-ion substitution of $\mathrm{CO}_{3}{ }^{2-}[14], \mathrm{Si}^{4+}[3,15]$, and so forth, whereas the substitution of $\mathrm{CO}_{3}{ }^{2-}$ along with other cations in the apatite structure was restricted to the cosubstitution of HA with the ionic pair of $\mathrm{Mg}^{2+} / \mathrm{CO}_{3}{ }^{2-}[4,16], \mathrm{Sr}^{2+} / \mathrm{CO}_{3}{ }^{2-}$ [17], and $\mathrm{Na}^{+} / \mathrm{CO}_{3}{ }^{2-}$ [18]. Although a few research works have been carried out on the synthesis of $\mathrm{SiO}_{4}{ }^{4-} / \mathrm{CO}_{3}{ }^{2-}$ cosubstitution in HA $[13,19]$, it is not clearly apparent whether $\mathrm{SiO}_{4}{ }^{4-}$ 
present in the material substituted completely the $\mathrm{PO}_{4}{ }^{3-}$ in the HA structure or whether the replacement was partial. It was reported [12] that both $\mathrm{CO}_{3}{ }^{2-}$ and $\mathrm{SiO}_{4}{ }^{4-}$ reduced HA crystallinity, and the structure could host only a limited amount of the two ions before collapsing. Additionally, the final product contained $\mathrm{CO}_{3}{ }^{2-}$ and $\mathrm{SiO}_{4}{ }^{4-}$, but there was a lack of experimental evidence on the competitive substitution of $\mathrm{CO}_{3}{ }^{2-}$ and $\mathrm{SiO}_{4}{ }^{4-}$ ions for $\mathrm{PO}_{4}{ }^{3-}$ ions [12]. Recently, an extensive study on the $\mathrm{SiO}_{4}{ }^{4-}$ and $\mathrm{CO}_{3}{ }^{2-}$ cosubstituted HA was reported [18]. However, the preparation methods were carried out under air atmosphere and used $\mathrm{CO}_{2}$ from the atmosphere as the $\mathrm{CO}_{3}{ }^{2-}$ source, and as such, there was no control of $\mathrm{CO}_{3}{ }^{2-}$ substitution level. Thus, the $\mathrm{CO}_{3}{ }^{2-}$ ion present could indeed be doped-HA, where the foreign ion is just adsorbed on the surface of the crystals [12]. Moreover, there were few research works that studied the mechanical properties of the ion-substituted HA after heat-treatment.

Therefore, the purpose of the present work is to investigate the simultaneous substitution of $\mathrm{SiO}_{4}{ }^{4-}$ and $\mathrm{CO}_{3}{ }^{2-}$ into the HA structure in order to obtain a product which is closer to the natural bone. The competition between $\mathrm{CO}_{3}{ }^{2-}$ and $\mathrm{SiO}_{4}{ }^{4-}$ for substituting the $\mathrm{PO}_{4}{ }^{3-}$ ions in the HA structure was also investigated. The aim of the work was also to evaluate the mechanical properties and the solubility of the siliconsubstituted carbonate HA as compared to that of carbonate HA.

\section{Experimental Procedure}

A precipitation method was adopted to prepare $\mathrm{CO}_{3} \mathrm{Ap}$ using $\mathrm{Ca}(\mathrm{OH})_{2}$ (96\% purity, FLUKA, 21181) and $\mathrm{H}_{3} \mathrm{PO}_{4}(15 \mathrm{M}$, MERCK, 100573, Germany) with $\mathrm{CO}_{2}$ gas as the carbonate source [14]. The $\mathrm{Ca} / \mathrm{P}$ molar ratio of the precursors was designed to be similar to $\mathrm{Ca} / \mathrm{P}$ molar ratio of biological bone, which is 1.67 [2]. Initially, a solution of $300 \mathrm{~mL}$ of $\mathrm{H}_{3} \mathrm{PO}_{4}$ $1 \mathrm{M}$ was gradually added to $500 \mathrm{~mL}$ of $\mathrm{Ca}(\mathrm{OH})_{2} 1 \mathrm{M}$ under vigorous stirring at $400 \mathrm{rpm}$, whilst $\mathrm{CO}_{2}$ gas was passed through the reaction flask during the reaction. According to Landi et al. [14], to obtain the highest carbonation degree and favor B-type $\mathrm{CO}_{3} \mathrm{Ap}$ precipitation with respect to A-type, the $\mathrm{CO}_{2}$ flow was set at $0.5 \mathrm{bubble} / \mathrm{s}$ as the outlet flux. Similar to $\mathrm{CO}_{3} \mathrm{Ap}$, the $\mathrm{Si}-\mathrm{CO}_{3} \mathrm{Ap}$ was prepared using silicon tetraacetate $\left[\mathrm{Si}\left(\mathrm{COOCH}_{3}\right)_{4}\right]$ (98\% purity, SIGMA-ALDRICH) as the Si precursor. Based on the chemical formula proposed by Gibson et al. [20] for silicon-substituted HA (Si-HA), the amount of reagents was calculated by assuming that one $\mathrm{SiO}_{4}{ }^{4-}$ ion would substitute for one $\mathrm{PO}_{4}{ }^{3-}$ ion based on a stoichiometric $\mathrm{HA}$; $\mathrm{Ca} /(\mathrm{P}+\mathrm{Si})$ molar ratio $=1.67 . \mathrm{Si}\left(\mathrm{COOCH}_{3}\right)_{4}$ was dissolved in the $\mathrm{Ca}(\mathrm{OH})_{2}$ solution under continuous stirring for 2 hours before adding the $\mathrm{H}_{3} \mathrm{PO}_{4}$ solution. In this research work, the Si content was chosen to be $1.6 \mathrm{wt} \%$ which had been shown to be the optimum amount for the enhancement of the mechanical properties of $\mathrm{Si}-\mathrm{HA}$ reported in our previous study [21], where the $\mathrm{Ca} /(\mathrm{P}+\mathrm{Si})$ ratio $=1.84$.

The reactions took place in a reaction flask which was placed in a heating mantle to control the reaction temperature at $40^{\circ} \mathrm{C} \pm 1$. The $\mathrm{pH}$ of the solution was monitored using a $\mathrm{pH}$ meter. $\mathrm{NH}_{4} \mathrm{OH} 29 \%$ (J.T.Baker, USA) was added to maintain the $\mathrm{pH}$ of the solution at $9.4 \pm 0.1$. After the reaction was completed, the slurry was continuously stirred for $2 \mathrm{~h}$ without $\mathrm{CO}_{2}$ gas. It was then allowed to mature at room temperature for $24 \mathrm{~h}$. Subsequently, it was filtered and washed with deionized water to remove any residue before being dried in an oven at $70^{\circ} \mathrm{C}$ for $24 \mathrm{~h}$. The dried $\mathrm{CO}_{3} \mathrm{Ap}$ and $\mathrm{Si}-$ $\mathrm{CO}_{3} \mathrm{Ap}$ powders were then ground with an agate pestle and mortar. For the DTS test, the $\mathrm{CO}_{3} \mathrm{Ap}$ and $\mathrm{Si}-\mathrm{CO}_{3} \mathrm{Ap}$ powders were compacted by uniaxial hydraulic pressing equipment using a die with $8 \mathrm{~mm}$ diameter at a pressure of $10 \mathrm{MPa}$. The thickness of samples was about $2.91-3.25 \mathrm{~cm}$. Alcohol $70 \%$ was used to clean the mold. The compacted samples were then heat-treated at different temperatures of 650,700 , and $750^{\circ} \mathrm{C}$ with a heating rate of $3^{\circ} \mathrm{C} / \mathrm{min}$ and soaked for $2 \mathrm{~h}$ in $\mathrm{CO}_{2}$ atmosphere $(80 \mathrm{~mL} / \mathrm{min})$ which was passed through $150 \mathrm{~mL}$ distilled water. The syntheses of $\mathrm{CO}_{3} \mathrm{Ap}$ and $\mathrm{Si}-\mathrm{CO}_{3} \mathrm{Ap}$ were repeated three times to confirm the reproducibility of the materials.

The as-synthesized and heat-treated powders were characterized using an X-ray diffractometer (XRD; D5000 Siemens) for phase identifications. Peak (002) was chosen for determining the crystallite size since it is one of the strongest peaks without any overlapping in the $\mathrm{CO}_{3} \mathrm{Ap}$ and $\mathrm{Si}-\mathrm{CO}_{3} \mathrm{Ap}$ patterns. The lattice parameters $(a$ and $c$ ) of the as-prepared $\mathrm{CO}_{3} \mathrm{Ap}$ and $\mathrm{Si}-\mathrm{CO}_{3} \mathrm{Ap}$ samples were determined through the $(h k l)$ peaks position of the apatite from XRD patterns according to (1) as follows $[22,23]$ :

$$
\frac{1}{d^{2}}=\frac{4}{3}\left(\frac{h^{2}+k h+l^{2}}{a^{2}}\right)+\frac{l^{2}}{c^{2}} .
$$

Fourier transform infrared spectroscopy (FTIR; PerkinElmer FT-IR 2000, FTIR spectrometer) was used to study the silicon and carbonate substitutions of the different functional groups, such as $\mathrm{OH}^{-}, \mathrm{PO}_{4}{ }^{3-}, \mathrm{CO}_{3}{ }^{2-}$, and $\mathrm{SiO}_{4}{ }^{4-}$ in the $\mathrm{CO}_{3} \mathrm{Ap}$ and $\mathrm{Si}-\mathrm{CO}_{3} \mathrm{Ap}$ samples. The carbonate content of powders was analyzed using an elemental analyzer $(\mathrm{CHN}$ test; Perkin Elmer series 2, $2400 \mathrm{CHNS} / \mathrm{O})$. The chemical composition ( $\mathrm{Si}$ and $\mathrm{Ca}$ ) was determined by inductive coupled plasma (ICP) spectrometer (ICP/AES, ARL-3410). X-ray fluorescence spectrometer (XRF; Rigaku RIX-300 wavelength dispersive) was used to study the $\mathrm{Ca} / \mathrm{P}$ ratio of the asprepared powders. The particle size of the powder (with ultrasonic dispersion) was measured using a Malvern Mastersizer $\mathrm{X}$ (Malvern Instruments, Malvern, UK). The powder before being characterized had been passed through a $75 \mu \mathrm{m}$ sieve.

The densities of the heat-treated $\mathrm{CO}_{3} \mathrm{Ap}$ and $\mathrm{Si}-\mathrm{CO}_{3} \mathrm{Ap}$ compacts were measured using Archimedes' principle. The diametral tensile strengths (DTS) of the heat-treated $\mathrm{CO}_{3} \mathrm{Ap}$ and $\mathrm{Si}-\mathrm{CO}_{3} \mathrm{Ap}$ compacts were tested at a strain rate of $0.5 \mathrm{~mm} / \mathrm{min}$. The DTS test involves compressing a sample diametrically, inducing a stress that causes the sample to yield in tension. In this test, a disk sample was placed between two platens and then vertically compressed until it broke [24]. During loading, the applied force was recorded and the tensile stress was calculated using (2)

$$
F_{t}=\frac{2 P_{\max }}{\pi d h},
$$

where $P_{\max }$ is maximum load at failure $(\mathrm{N})$ and $h$ and $d$ are the thickness and diameter of the compacts $(\mathrm{mm})$, respectively. 
Table 1: Physical and chemical properties of the as-synthesized $\mathrm{CO}_{3} \mathrm{Ap}$ and $\mathrm{Si}-\mathrm{CO}_{3} \mathrm{Ap}$ samples.

\begin{tabular}{|c|c|c|c|c|c|}
\hline \multirow{2}{*}{ Sample } & \multicolumn{2}{|r|}{ Si content (wt\%) } & \multicolumn{2}{|r|}{$\mathrm{Ca} / \mathrm{P}$} & \multirow{2}{*}{ Mean particle size $(\mu \mathrm{m})$} \\
\hline & Starting value & Measured value (ICP/in powder) & Starting value & Measured value (XRF) & \\
\hline $\mathrm{CO}_{3} \mathrm{Ap}$ & 0 & - & 1.67 & 2.08 & 2.52 \\
\hline $\mathrm{Si}-\mathrm{CO}_{3} \mathrm{Ap}$ & 1.6 & 0.85 & 1.84 & 2.16 & 0.98 \\
\hline
\end{tabular}

The solubility evaluation was performed in triplicate on the as-synthesized $\mathrm{CO}_{3} \mathrm{Ap}$ and $\mathrm{Si}-\mathrm{CO}_{3} \mathrm{Ap}$ compacts (8 mm diameter die, $10 \mathrm{MPa}$ ) by immersing the compacts in a simulated body luid (SBF) solution at $36.5^{\circ} \mathrm{C}$. The SBF solution was prepared according to the procedure described by Kokubo and Takadama [25]. The tests were carried out within 1 and 7 days. After the predetermined soaking time, the samples were removed and the liquid mediums were analyzed by ICP. The released ion was estimated by subtracting the initial ion concentration of the SBF solution from the ion concentration of the SBF solution after immersion.

Statistical analysis was performed to evaluate the statistical differences between the sample sets by employing one factor analysis of variance (ANOVA) when comparing more than two sample populations. Significant differences were considered at the $95 \%$ level $(P<0.05)$.

\section{Results and Discussion}

3.1. Physical and Chemical Composition Analyses. Table 1 shows the physical and chemical properties of the assynthesized $\mathrm{CO}_{3} \mathrm{Ap}$ and $\mathrm{Si}-\mathrm{CO}_{3} \mathrm{Ap}$ samples. The mean particle size of the as-synthesized $\mathrm{Si}-\mathrm{CO}_{3} \mathrm{Ap}$ sample is significantly smaller than that of the as-synthesized $\mathrm{CO}_{3} \mathrm{Ap}$ sample. This can be attributed to the substitution of $\mathrm{Si}$ in the HA structure, as reported in previous research works $[21,26]$.

In the same table, the $\mathrm{Ca} / \mathrm{P}$ molar ratios of the assynthesized $\mathrm{CO}_{3} \mathrm{Ap}$ and $\mathrm{Si}-\mathrm{CO}_{3} \mathrm{Ap}$ samples show much higher values than those of the predetermined ratios. This indicated that the substitution of $\mathrm{CO}_{3}{ }^{2-}$ and $\mathrm{SiO}_{4}{ }^{4-}$ ions for the $\mathrm{PO}_{4}{ }^{3-}$ groups in the $\mathrm{HA}$ had taken place. These substitutions reduce the amount of $\mathrm{PO}_{4}{ }^{3-}$ group, thus leading to an increase in the $\mathrm{Ca} / \mathrm{P}$ ratio $[14,20]$. However, the $\mathrm{Ca} / \mathrm{P}$ ratio in this study was in the range of the $\mathrm{Ca} / \mathrm{P}$ molar ratio of $\mathrm{CO}_{3}$ Ap reported previously, which was of 1.7-2.6 [27].

The Si contents are also included in Table 1. Si measured in the as-synthesized $\mathrm{Si}-\mathrm{CO}_{3} \mathrm{Ap}$ sample is about $0.85 \mathrm{wt} \%$, and this is much lower than the starting value $(1.6 \mathrm{wt} \%)$. The rest of the Si unaccounted for will be explained in the FTIR analysis. It was suggested that an amount of only $1 \mathrm{wt} \% \mathrm{Si}$ substituted into HA was sufficient to elicit important bioactive improvements [12], and, hence, the Si-substituted $\mathrm{CO}_{3} \mathrm{Ap}$ in this research work could be considered to approach this enhancement.

After heat-treatment at a temperature range of 650$750^{\circ} \mathrm{C}$, the carbonate amount slightly decreases compared to the as-prepared samples (Table 2). This is due to the fact that carbonate absorbed had desorbed upon heat-treatment. The amount of carbonate is close to the typical amount of carbonate in human bone [28].
TABLE 2: Carbonate contents in the $\mathrm{CO}_{3} \mathrm{Ap}$ and $\mathrm{Si}-\mathrm{CO}_{3} \mathrm{Ap}$ samples before and after heat-treatment.

\begin{tabular}{lcccc}
\hline Sample & $\begin{array}{c}\mathrm{CO}_{3}(\mathrm{wt} \%) \\
\text { As-prepared } \\
\text { powders }\end{array}$ & \multicolumn{2}{c}{$\mathrm{CO}_{3}(\mathrm{wt} \%)$} & Heat-treated powders \\
& & $650^{\circ} \mathrm{C}$ & $700^{\circ} \mathrm{C}$ & $750^{\circ} \mathrm{C}$ \\
\hline $\mathrm{CO}_{3} \mathrm{Ap}$ & 10.75 & 10.1 & 10.05 & 10.05 \\
$\mathrm{Si}_{-} \mathrm{CO}_{3} \mathrm{Ap}$ & 10.25 & 9.4 & 9.4 & 8.4 \\
\hline
\end{tabular}

TABLE 3: Lattice parameters and crystallite size of the as-synthesized $\mathrm{CO}_{3} \mathrm{Ap}$ and $\mathrm{Si}-\mathrm{CO}_{3} \mathrm{Ap}$ powders.

\begin{tabular}{lccc}
\hline Sample & \multicolumn{2}{c}{ Lattice parameters $\left(\mathrm{A}^{\circ}\right)$} & Crystallite size $(\mathrm{nm})$ \\
& $a \pm 0.003$ & $c \pm 0.003$ & - \\
$\mathrm{HA} \mathrm{[26]}$ & 9.4366 & 6.8905 & $23.12 \pm 0.03$ \\
$\mathrm{CO}_{3} \mathrm{Ap}$ & 9.3860 & 6.8963 & $16.82 \pm 0.02$ \\
$\mathrm{Si}-\mathrm{CO}_{3} \mathrm{Ap}$ & 9.4061 & 6.9057 & \\
\hline
\end{tabular}

3.2. XRD Analysis. Figure 1 shows the $\mathrm{XRD}$ patterns of the assynthesized $\mathrm{CO}_{3} \mathrm{Ap}$ and $\mathrm{Si}-\mathrm{CO}_{3} \mathrm{Ap}$ powders. The broad peaks indicate the formation of HA phase with low crystallinity, and no secondary crystalline phases were observed. The poor crystallinity was due to the low synthesis temperature and the substitution of $\mathrm{SiO}_{4}{ }^{4-}$ and $\mathrm{CO}_{3}{ }^{2-}$ ions limited the crystallization of the HA phase [18, 21].

The crystallite size determined using Scherrer's equation and the lattice parameters are given in Table 3. The $\mathrm{CO}_{3}{ }^{2-}$ and $\mathrm{SiO}_{4}{ }^{4-}$ substitutions in $\mathrm{HA}$ structure led to changes in the crystal lattice parameters $[4,18]$. Previous studies had shown that the $a$-axis decreased and the $c$-axis increased with increasing $\mathrm{CO}_{3}{ }^{2-}$ or $\mathrm{SiO}_{4}{ }^{4-}$ in the $\mathrm{HA}$ structure $[3,6]$. The values presented in Table 3 for the as-prepared powders in this present research work also show a similar trend with previous works. The $\mathrm{SiO}_{4}{ }^{4-}$ groups are larger and have a more negative charge than either $\mathrm{PO}_{4}{ }^{3-}$ or $\mathrm{CO}_{3}{ }^{2-}$ ions $[15$, 18]. Additionally, the substitution of $\mathrm{SiO}_{4}{ }^{4-}$ and $\mathrm{CO}_{3}{ }^{2-}$ for $\mathrm{PO}_{4}{ }^{3-}$ contributes to reducing the crystallite size, as has been observed previously in other studies $[12,18,21]$.

Numerous studies showed that both $a$ - and $c$-axis dimensions increased with the silicon content $[18,29,30]$. Considering the substitution of $\mathrm{SiO}_{4}{ }^{4-}$ in the $\mathrm{CO}_{3} \mathrm{Ap}$, it is possible that, $a$ - and $c$-axis dimensions are higher than those of $\mathrm{CO}_{3} \mathrm{Ap}$ (Table 3) because the ionic bond length of a $\mathrm{Si}-\mathrm{O}$ bond $(0.166 \mathrm{~nm})$ is greater than that of $\mathrm{P}-\mathrm{O}$ bond $(0.157 \mathrm{~nm})$. The radius of the $\mathrm{PO}_{4}{ }^{3-}$ tetrahedron would be smaller than that of the $\mathrm{SiO}_{4}{ }^{4-}$ tetrahedron that results in the change of $\mathrm{HA}$ lattice parameters. 


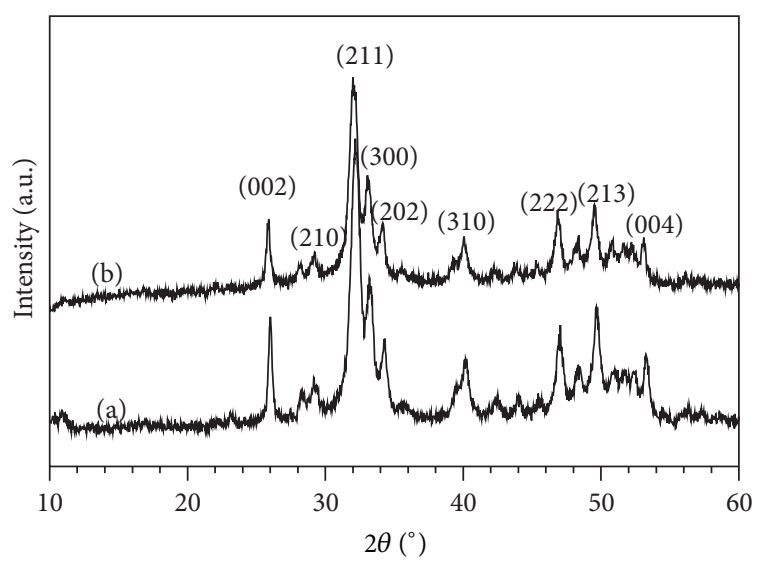

FIGURE 1: XRD patterns of the as-prepared powders: (a) $\mathrm{CO}_{3} \mathrm{Ap}$ and (b) $\mathrm{Si}-\mathrm{CO}_{3} \mathrm{Ap}$.

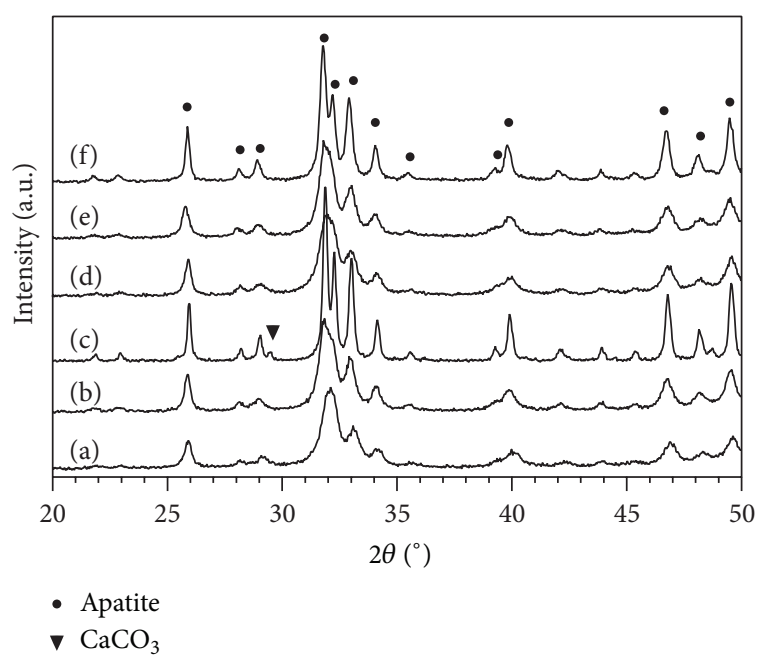

FIGURE 2: XRD patterns of the samples after heat-treatment of Si$\mathrm{CO}_{3} \mathrm{Ap}$ at (a) $650^{\circ} \mathrm{C}$, (b) $700^{\circ} \mathrm{C}$, and (c) $750^{\circ} \mathrm{C}$ and of $\mathrm{CO}_{3} \mathrm{Ap}$ at (d) $650^{\circ} \mathrm{C}$, (e) $700^{\circ} \mathrm{C}$, and (f) $750^{\circ} \mathrm{C}$.

After heat-treatment at $650^{\circ} \mathrm{C}$ to $700^{\circ} \mathrm{C}$, pure $\mathrm{CO}_{3} \mathrm{Ap}$ and $\mathrm{Si}-\mathrm{CO}_{3} \mathrm{Ap}$ are still observed and no secondary phases are detected (Figure 2(a), (b), (d), and (e)). However, a new phase, $\mathrm{CaCO}_{3}$, is clearly observed in $\mathrm{Si}-\mathrm{CO}_{3} \mathrm{Ap}$ samples heattreated at $750^{\circ} \mathrm{C}$ due to the decomposition of the $\mathrm{Si}-\mathrm{CO}_{3} \mathrm{Ap}$ samples.

Sintering of $\mathrm{CO}_{3} \mathrm{Ap}$ at high temperatures $\left(\geq 900^{\circ} \mathrm{C}\right)[15$, 31] produces hydroxyapatite ( $\mathrm{HA}$ ) and $\mathrm{CaO}$. In the $\mathrm{CO}_{2}$-rich atmosphere, the $\mathrm{CaCO}_{3}$ obtained was due to the reaction of $\mathrm{CaO}$ and $\mathrm{CO}_{2}$. Therefore, a mixture of $\mathrm{CO}_{3} \mathrm{Ap}$ and $\mathrm{CaCO}_{3}$ is observed after heat-treatment in $\mathrm{CO}_{2}$ atmosphere. The decomposition temperature decreased with an increase of the carbonate [31] and/or silicon content [15, 32]. Since the heat-treatment process was carried out at low temperatures, such decomposition did not occur in the $\mathrm{CO}_{3}$ Ap sample but did occur in $\mathrm{Si}-\mathrm{CO}_{3} \mathrm{Ap}$ sample at $750^{\circ} \mathrm{C}$. The simultaneous substitution of $\mathrm{SiO}_{4}{ }^{4-}$ and $\mathrm{CO}_{3}{ }^{2-}$ ions for the $\mathrm{PO}_{4}{ }^{3-}$ ions of the HA structure increased the defects in HA structure and

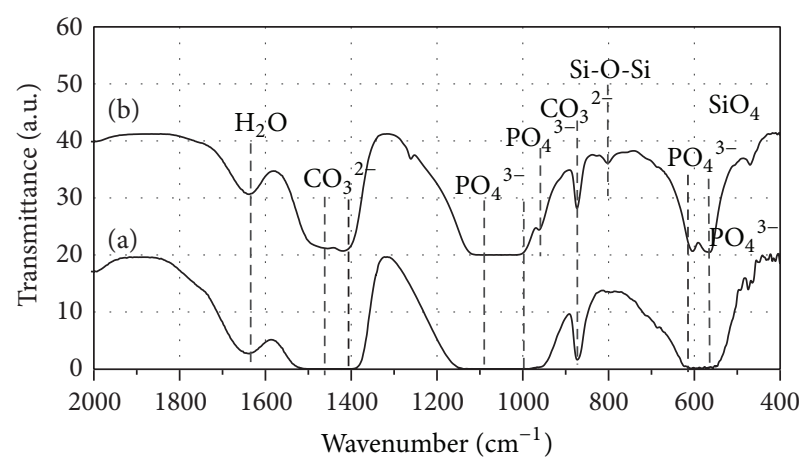

FIGURE 3: FTIR spectra of the as-prepared powders: (a) $\mathrm{CO}_{3} \mathrm{Ap}$ and (b) $\mathrm{Si}-\mathrm{CO}_{3} \mathrm{Ap}$.

produced more $\mathrm{OH}^{-}$vacancies [13] compared to $\mathrm{CO}_{3} \mathrm{Ap}$. The formation of $\mathrm{OH}$ vacancies has been proven to accelerate the decomposition process [23]. Thus, the formation of $\mathrm{CaCO}_{3}$ in the $\mathrm{Si}-\mathrm{CO}_{3} \mathrm{Ap}$ could be explained by a similar mechanism as the decomposition of $\mathrm{CO}_{3} \mathrm{Ap}$.

3.3. FTIR Analysis. FTIR spectrum of each powder (Figure 3) shows the characteristic absorption bands of HA corresponding to stretching vibration of $\mathrm{PO}_{4}{ }^{3-}$ ions at $567,604 \mathrm{~cm}^{-1}(v 4)$; $963 \mathrm{~cm}^{-1}(v 1) ; 1045 \mathrm{~cm}^{-1}(v 3)$; in all the as-synthesized powder bands. The broad band at about $1638 \mathrm{~cm}^{-1}$ corresponds to in-plane water bending mode. The $\mathrm{CO}_{3}{ }^{2-}$ groups substituted in B-site were confirmed with typical bands around $874 \mathrm{~cm}^{-1}$ (v2), $1470 \mathrm{~cm}^{-1}[4,18,33]$, whereas the bands located at $1505 \mathrm{~cm}^{-1}$ could be attributed to A-type $\mathrm{CO}_{3} \mathrm{Ap} \mathrm{[28]}$.

The characteristic $\mathrm{OH}^{-}$bands of $\mathrm{HA}$ at $630 \mathrm{~cm}^{-1}$ are not clearly visible in all FITR spectra. In fact, a similar decrease in the intensity of $\mathrm{OH}^{-}$signals was also observed due to the substitution of $\mathrm{CO}_{3}{ }^{2-}$ at the $\mathrm{OH}^{-}$lattice of HA [33]. In this case, the substitution of $\mathrm{CO}_{3}{ }^{2-}$ and $\mathrm{SiO}_{4}{ }^{4-}$ ions for $\mathrm{PO}_{4}{ }^{3-}$ would create an $\mathrm{OH}^{-}$loss needed to compensate the charge balance, thus resulting in the weak of $\mathrm{OH}^{-}$signal.

Additional bands are also observed in the $\mathrm{Si}-\mathrm{CO}_{3} \mathrm{Ap}$ sample at about $800 \mathrm{~cm}^{-1}$ and $480 \mathrm{~cm}^{-1}$ which do not appear in $\mathrm{CO}_{3} \mathrm{Ap}$ sample. The band at $480 \mathrm{~cm}^{-1}$ is assigned to the $\mathrm{SiO}_{4}{ }^{4-}$ in the apatite structure [15]. However, the band at about $800 \mathrm{~cm}^{-1}$ might be assigned to either the silicate group [30] or to the $\mathrm{O}-\mathrm{Si}-\mathrm{O}$ bending in the $\mathrm{SiO}_{2}$ amorphous phase $[22,34]$. As detected by ICP, the amount of $\mathrm{Si}$ in $\mathrm{Si}-\mathrm{CO}_{3} \mathrm{Ap}$ sample is much lower than the starting value (Table 1); the silicate species which could not totally be incorporated in the apatite structure exist on the surface of the materials as an amorphous phase $[22,35]$ and/or remain in mother liquors after precipitation [36]. The remaining Si suggests that the competition arising between the $\mathrm{SiO}_{4}{ }^{4-}$ and $\mathrm{CO}_{3}{ }^{2-}$ ions occupies the $\mathrm{PO}_{4}{ }^{3-}$ sites. The polymerization of the silicate species at the surface was reported elsewhere [37]. In another research work [38], the amorphous $\mathrm{SiO}_{2}$ phase in $\beta$ TCP containing Si-substitution showed a significantly higher MC3T3-E1 osteoblast-like cell number compared to pure $\beta$ TCP. Therefore, the presence of $\mathrm{SiO}_{2}$ would not cause toxicity to the cells and would not affect cell differentiation. 


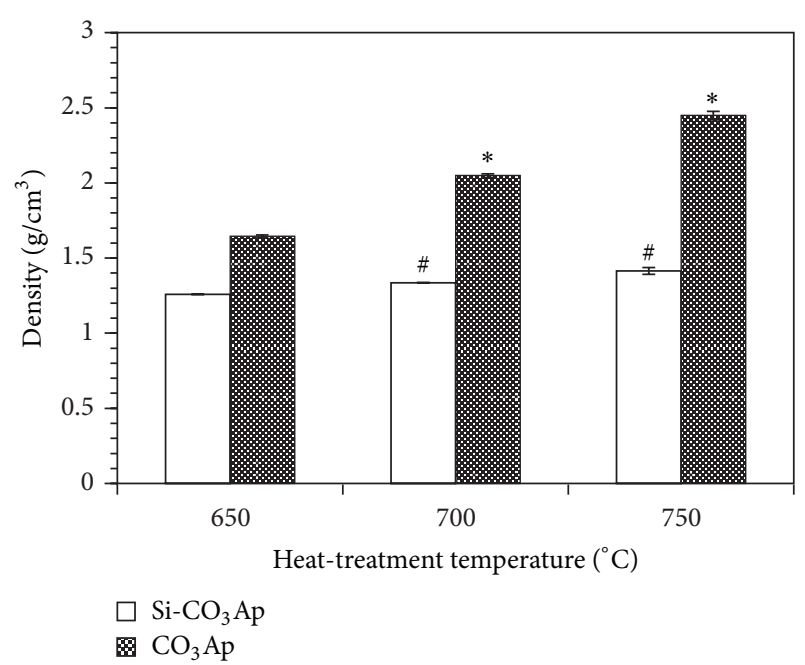

FIgURE 4: Density of samples after heat-treatment at different temperatures. ${ }^{*} P<0.05$ and ${ }^{\#} P<0.05$, statistically different compared to $\mathrm{CO}_{3} \mathrm{Ap}$ and Si-CO $\mathrm{CO}_{3} \mathrm{Ap}$ heat-treated at $650^{\circ} \mathrm{C}$, respectively; $n=8$.

The substitutions of $\mathrm{CO}_{3}{ }^{2-}$ and $\mathrm{SiO}_{4}{ }^{4-}$ groups for $\mathrm{PO}_{4}{ }^{3-}$ change the symmetry and stability of an apatite structure [39]. As a result of these substitutions, shifts and splitting of the $\mathrm{PO}_{4}$ vibration bands at about $500-700 \mathrm{~cm}^{-1}$ occur in the apatite IR spectra (Figure 3).

It has already been reported that the calcium phosphate apatite constituent of bone mineral consists of a mixed AB-type substitution [40]. The results from the present study confirm the formation of AB-type carbonated apatite along with the presence of $\mathrm{Si}$ in the structure. Thus, this complex substitution type is also of utmost importance when the development of a synthetic bone-substitute material is sought.

\subsection{Evaluation of Mechanical Properties and Microstructure.} The mechanical and physical properties were evaluated in terms of diametral tensile strength (DTS) and bulk density. In Figure 4, the density of $\mathrm{CO}_{3} \mathrm{Ap}$ sample is higher than that of $\mathrm{Si}-\mathrm{CO}_{3} \mathrm{Ap}$ sample at any heat-treatment temperatures. This can be explained by the higher lattice parameters of both $\mathrm{CO}_{3}{ }^{2-}$ and $\mathrm{SiO}_{4}{ }^{4-}$ cosubstitution compared to the single $\mathrm{CO}_{3}{ }^{2-}$ substitution (Table 3).

It can also be seen that the density of the $\mathrm{CO}_{3} \mathrm{Ap}$ samples significantly increases with increasing heat-treatment temperatures, whilst there is only a slight change in the density of the $\mathrm{Si}-\mathrm{CO}_{3} \mathrm{Ap}$ samples. The substitution of $\mathrm{Si}$ reduced the density of the materials compared to HA as reported previously $[15,21]$ due to the change of unit cell parameters in the silicon-substituted materials. Therefore, the effect of silicon became significant which slowed down the densification process upon heat-treatment. In the present research work, the densities of $\mathrm{CO}_{3} \mathrm{Ap}$ and $\mathrm{Si}-\mathrm{CO}_{3} \mathrm{Ap}$ are significantly lower compared to that of a fully dense HA $\left(3.16 \mathrm{~g} / \mathrm{cm}^{3}\right)$ due to the low heat-treatment temperatures.

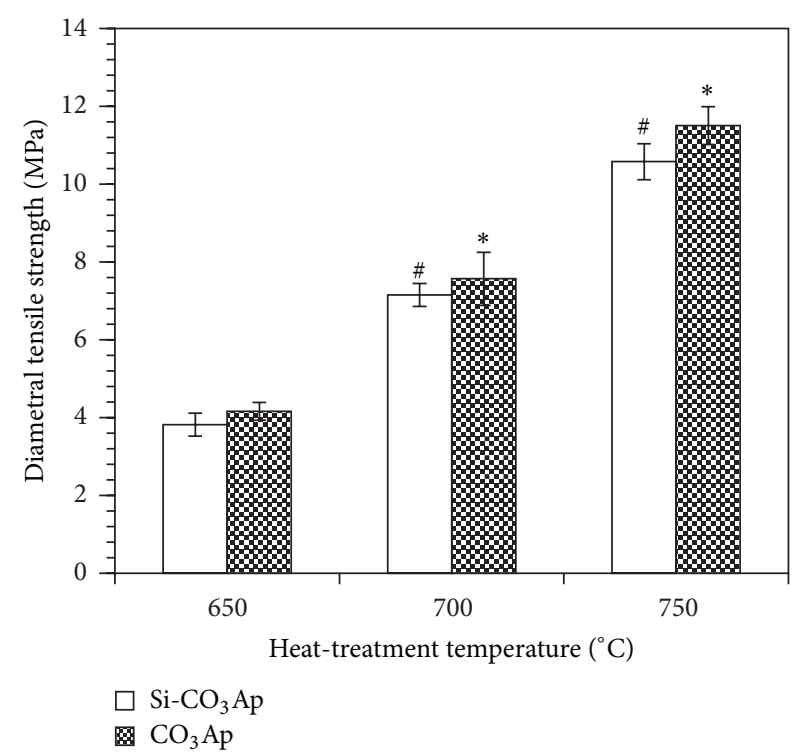

FIgURE 5: Diametral tensile strength (DTS) of samples at different temperatures. ${ }^{*} P<0.05$ and ${ }^{\#} P<0.05$, statistically different compared to $\mathrm{CO}_{3} \mathrm{Ap}$ and $\mathrm{Si}-\mathrm{CO}_{3} \mathrm{Ap}$ heat-treated at $650^{\circ} \mathrm{C}$, respectively; $n=8$.

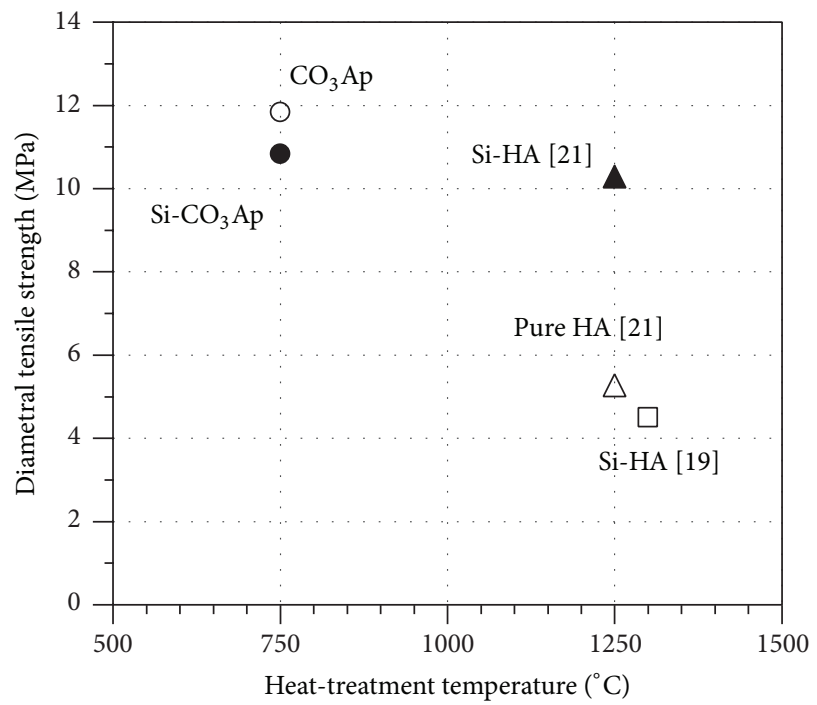

FIGURE 6: DTS versus heat-treatment temperatures for various carbonate hydroxyapatites.

Figure 5 shows that the DTS of both $\mathrm{CO}_{3} \mathrm{Ap}$ and $\mathrm{Si}$ $\mathrm{CO}_{3} \mathrm{Ap}$ samples significantly increase with increasing temperatures. The increase in DTS value of $\mathrm{CO}_{3} \mathrm{Ap}$ with the increasing heat-treatment temperatures can be explained by the increase in density as shown in Figure 4. However, although a slightly higher density was obtained for the Si$\mathrm{CO}_{3} \mathrm{Ap}$, the DTS of $\mathrm{Si}-\mathrm{CO}_{3} \mathrm{Ap}$ increases significantly with increasing heat-treatment temperatures. This is due to the cosubstitution of $\mathrm{CO}_{3}{ }^{2-}$ and $\mathrm{SiO}_{4}{ }^{4-}$. This cosubstitution induced the smaller particle size (Table 1). In addition, $\mathrm{Si}$ substitution was reported to impede grain growth during heat-treatment [41] and so increased the DTS value. 


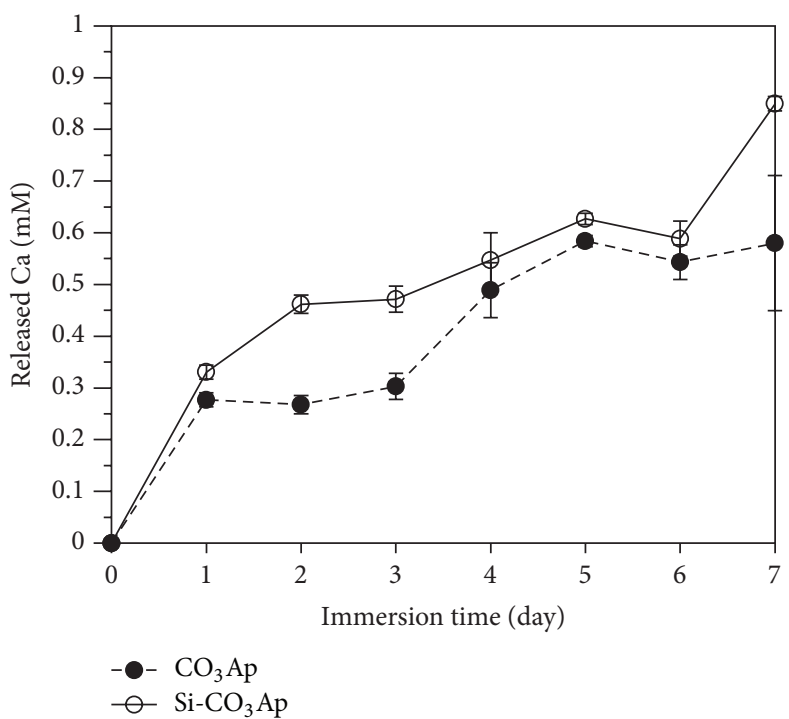

(a)

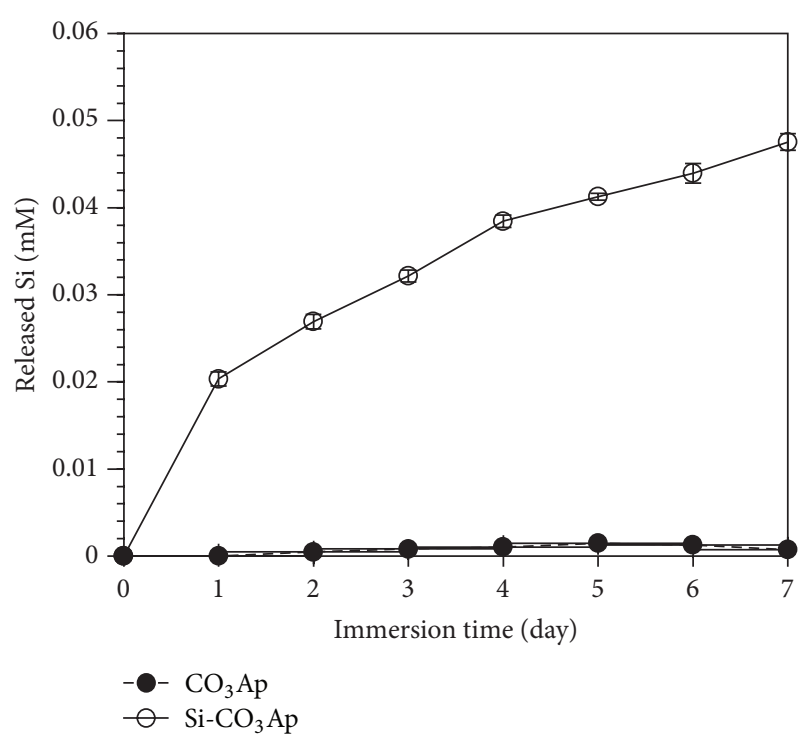

(b)

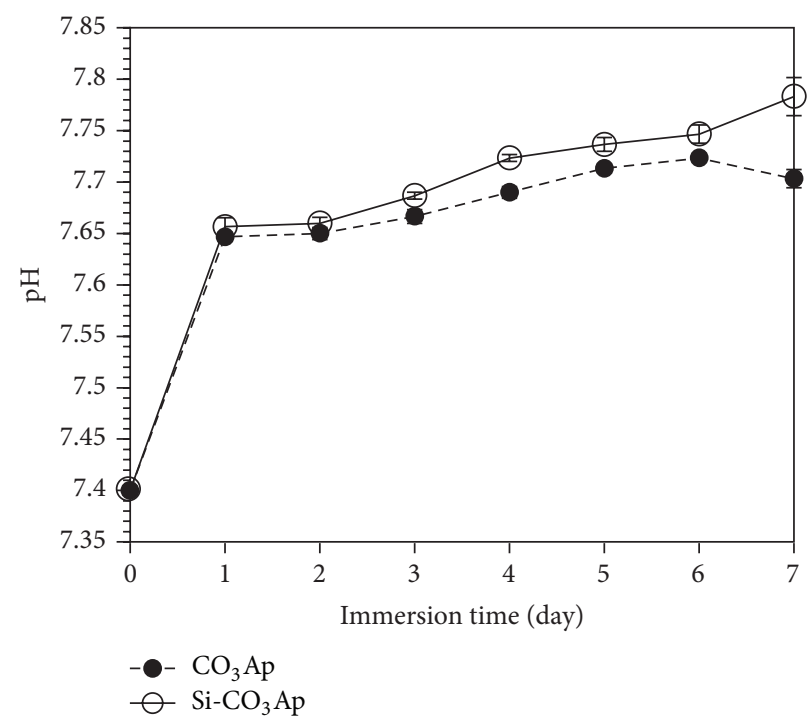

(c)

FIGURE 7: Released ions and $\mathrm{pH}$ of SBF solution after immersion: (a) released $\mathrm{Ca}$, (b) released $\mathrm{Si}$, and (c) $\mathrm{pH}$.

By comparison, the DTS of $\mathrm{CO}_{3}$ Ap samples appear to be slightly higher compared to those of $\mathrm{Si}-\mathrm{CO}_{3} \mathrm{Ap}$ samples. This difference in strength was evaluated to be $\rho>0.05$, and as such, this difference in DTS value of $\mathrm{Si}-\mathrm{CO}_{3} \mathrm{Ap}$ is insignificant compared to $\mathrm{CO}_{3} \mathrm{Ap}$. However, its density is significantly lower $(\rho<0.05)$ indicating the positive effect of $\mathrm{SiO}_{4}{ }^{4-}$ and $\mathrm{CO}_{3}{ }^{2-}$ cosubstitutions on this matter. As reported, the effect of silicon on the increase of mechanical strength was evidenced at higher heat-treatment temperatures, that is, $1200^{\circ} \mathrm{C}$ and above, as compared to Si-free samples [21]. Conversely, at lower temperatures, this effect was not so apparent where the strengths of $\mathrm{Si}$-samples and $\mathrm{Si}$-free samples were comparable based on previous studies [21, 41] and even lower [19] due to the lower density. Hence, due to the low heat-treatment temperatures employed in this research work, the difference in strength between $\mathrm{CO}_{3} \mathrm{Ap}$ and $\mathrm{Si}-\mathrm{CO}_{3} \mathrm{Ap}$ samples is not that significant.

Figure 6 presents a comparison of the DTS values of the present materials at $750^{\circ} \mathrm{C}$ with those of samples in previous research works $[19,21]$. Interestingly, at the same Si content (about $0.8 \mathrm{wt} \%$ ), the DTS values of $\mathrm{CO}_{3} \mathrm{Ap}$ and $\mathrm{Si}-\mathrm{CO}_{3} \mathrm{Ap}$ at $750^{\circ} \mathrm{C}$ are about $10.8 \pm 0.3-11.8 \pm 0.4 \mathrm{MPa}$, and these are higher than those of $\mathrm{Si}$-substituted $\mathrm{HA}$ samples at $1250^{\circ} \mathrm{C}$ [21] and much higher than that of Si-HA sample at $1300^{\circ} \mathrm{C}$ [19]. This demonstrates that, at these low heat-treatment temperatures, the cosubstitution of carbonate and $\mathrm{Si}$ in the HA structure would increase the strength of the final product.

In Figure 6, the DTS of Si-substituted HA sample [21] is higher than that of pure $\mathrm{HA}$ because the $\mathrm{SiO}_{4}{ }^{4-}$ substitution impeded grain growth at high temperatures and, therefore, 
increased the strength of the materials [41]. The DTS of $\mathrm{CO}_{3} \mathrm{Ap}$ and $\mathrm{Si}-\mathrm{CO}_{3} \mathrm{Ap}$ in the present work are also higher than that of pure HA. It was explained [42] that the $\mathrm{CO}_{3}{ }^{2-}$ and $\mathrm{SiO}_{4}{ }^{4-}$ substitutions also reduced the grain size of the final product and resulted in an increase of the strength of the samples.

3.5. Solubility Evaluation. In the case of crystalline HA, the degree of micro- and macroporosities, defect structure, and amount and type of other phases present have a significant influence on the dissolution rate [43]. In this study, the immersion of the $\mathrm{CO}_{3} \mathrm{Ap}$ and $\mathrm{Si}-\mathrm{CO}_{3} \mathrm{Ap}$ compacts (surface area $=150.8 \mathrm{~mm}^{2}$ ) into $\mathrm{SBF}$ solution produced noticeable changes in the ion concentrations of the solution. Figures $7(\mathrm{a}), 7(\mathrm{~b})$, and 7(c) show the ion concentration of $\mathrm{Ca}, \mathrm{Si}$ and changes in $\mathrm{pH}$ value of the medium after a certain period of immersion time, respectively. According to Boanini et al. [12], crystallinity and crystal dimensions significantly affected the solubility and, as a consequence, ion release. Thus, a decrease in structural order due to the presence of foreign ions might be responsible for the observed increase in solubility.

In Figure 7, the $\mathrm{Ca}^{2+}$ and $\mathrm{Si}^{4+}$ ion concentrations as well as the $\mathrm{pH}$ of the SBF solution increase with soaking duration which indicates the dissolution of $\mathrm{Ca}^{2+}$ and $\mathrm{Si}^{4+}$ ions. It had been reported that the initial dissolution of implant materials plays an important role in enhancing their bonding to the bone [32]. With an increase in the soaking duration, $\mathrm{Ca}^{2+}$ concentrations and $\mathrm{pH}$ value continuously increase due to the ionic exchange between $\mathrm{H}^{+}$within the SBF solution and $\mathrm{Ca}^{2+}$ in the $\mathrm{CO}_{3} \mathrm{Ap}$ and $\mathrm{Si}-\mathrm{CO}_{3} \mathrm{Ap}$ compacts $[44,45]$. The increase of solution $\mathrm{pH}$ generally facilitates the nucleation of apatite [46].

The release of $\mathrm{Si}^{4+}$ ions was also observed continuously over the whole investigation period. It was reasoned out that the amorphous layer surrounding the apatite grains dissolved within the first period of immersion in SBF leaving a more stable and less soluble core [13]. As solubility is highly sensitive to the structural and chemical compositions of the apatite samples, the crystallite size is a key factor for in vitro behavior of synthetic apatite [47]. In this manner, the resorbability of $\mathrm{CO}_{3} \mathrm{Ap}$ and $\mathrm{Si}-\mathrm{CO}_{3} \mathrm{Ap}$ could be promoted by a smaller crystallite size when $\mathrm{CO}_{3}{ }^{2-}$ and $\mathrm{SiO}_{4}{ }^{4-}$ were cosubstituted; the amorphous shell can be thicker and yield a more intense and prolonged ion release [13]. In addition, the $\mathrm{Ca}^{2+}$ release in $\mathrm{Si}-\mathrm{CO}_{3} \mathrm{Ap}$ compacts is slightly higher compared to $\mathrm{CO}_{3} \mathrm{Ap}$, which suggests a better solubility (Figure $7(\mathrm{a})$ ) that leads to a faster super-saturation with respect to HA, a faster nucleation, and growth of apatite on the surface of the compacts [36].

By comparison, the $\mathrm{Ca}^{2+}$ release for $\mathrm{CO}_{3} \mathrm{Ap}$ and $\mathrm{Si}-$ $\mathrm{CO}_{3}$ Ap samples in this study is much higher than that of $\mathrm{Mg}$ substituted fluorapatite [48] and HA $[44,49]$ under the same conditions. It was reported that the solubility of materials increases with increasing ionic substitutions into the HA lattice and decreasing crystallinity which is represented by the higher ion release in the SBF solution $[13,16,49]$. Therefore, the $\mathrm{CO}_{3} \mathrm{Ap}$ and $\mathrm{Si}-\mathrm{CO}_{3} \mathrm{Ap}$ obtained in this work are of higher solubility compared to the above-mentioned materials.
Based on the solubility evaluations using SBF, the solubility of $\mathrm{CO}_{3} \mathrm{Ap}$ and $\mathrm{Si}-\mathrm{CO}_{3} \mathrm{Ap}$ is such that it is predicted that ions would continuously exist in actual physiological conditions. This is further reinforced by a previous work [13]. These materials could supply elements which are essential for osteoblast activity and new bone tissue formation [13]. The simultaneous presence of such elements can further enhance the cell response.

\section{Conclusions}

Carbonate hydroxyapatite and silicon-substituted carbonate hydroxyapatite powders were successfully synthesized by a simple and high-yield process. The crystallite and mean particle size of $\mathrm{Si}-\mathrm{CO}_{3} \mathrm{Ap}$ sample was significantly smaller than that of $\mathrm{CO}_{3} \mathrm{Ap}$ sample due to the cosubstitution of $\mathrm{SiO}_{4}{ }^{4-}$ and $\mathrm{CO}_{3}{ }^{2-}$ in the HA structure. No secondary phases were detected in $\mathrm{CO}_{3} \mathrm{Ap}$ and $\mathrm{Si}-\mathrm{CO}_{3} \mathrm{Ap}$ samples after heattreatment in the temperature range of $650^{\circ} \mathrm{C}$ to $700^{\circ} \mathrm{C} \cdot \mathrm{CaCO}_{3}$ was observed in $\mathrm{Si}-\mathrm{CO}_{3} \mathrm{Ap}$ sample after heat-treatment at $750^{\circ} \mathrm{C}$, whilst the purity of $\mathrm{CO}_{3} \mathrm{Ap}$ was retained. The $\mathrm{SiO}_{4}{ }^{4-}$ and $\mathrm{CO}_{3}{ }^{2-}$ cosubstituted $\mathrm{HA}$ structure led to a significant decrease in density compared to a single $\mathrm{CO}_{3}{ }^{2-}$ substituted HA structure, whilst the DTS of both samples showed insignificant differences.

The competition between $\mathrm{SiO}_{4}{ }^{4-}$ and $\mathrm{CO}_{3}{ }^{2-}$ ions had taken place to occupy the $\mathrm{PO}_{4}{ }^{3-}$ site. $\mathrm{Si}-\mathrm{CO}_{3} \mathrm{Ap}$ existed in the form of $\mathrm{AB}$-type carbonated apatite, and the presence of $\mathrm{SiO}_{4}{ }^{4-}$ in the structure is of utmost interest in developing a synthetic bone-substitute material. The total amount of carbonate and silicon and the crystal size of the powder obtained mimic those of biological apatites. The silicon substitution improved the solubility of $\mathrm{Si}-\mathrm{CO}_{3} \mathrm{Ap}$ which prolongs the ion release compared to that of $\mathrm{Si}$-free $\mathrm{CO}_{3} \mathrm{Ap}$. The present materials possess low crystallinity and the $\mathrm{CO}_{3}{ }^{2-}$ content is close to that found in natural bone, and, in combination with the high strength, these materials could be ideal for bone substitutes.

\section{Conflict of Interests}

The authors declare that there is no conflict of interests regarding the publication of this paper.

\section{Acknowledgment}

The authors would like to thank AUN/SEED-Net under the Japan International Cooperation Agency (JICA) and Malaysia Technology Development Corporation (MTDC) for financial support.

\section{References}

[1] S. V. Dorozhkin, "Nanosized and nanocrystalline calcium orthophosphates," Acta Biomaterialia, vol. 6, no. 3, pp. 715-734, 2010.

[2] A. J. Wagoner Johnson and B. A. Herschler, "A review of the mechanical behavior of $\mathrm{CaP}$ and $\mathrm{CaP} /$ polymer composites for 
applications in bone replacement and repair," Acta Biomaterialia, vol. 7, no. 1, pp. 16-30, 2011.

[3] S. Gomes, J.-M. Nedelec, E. Jallot, D. Sheptyakov, and G. Renaudin, "Silicon location in silicate-substituted calcium phosphate ceramics determined by neutron diffraction," Crystal Growth and Design, vol. 11, no. 9, pp. 4017-4026, 2011.

[4] J. Kolmas, A. Jaklewicz, A. Zima et al., "Incorporation of carbonate and magnesium ions into synthetic hydroxyapatite: the effect on physicochemical properties," Journal of Molecular Structure, vol. 987, no. 1-3, pp. 40-50, 2011.

[5] M. Lombardi, P. Palmero, K. Haberko, W. Pyda, and L. Montanaro, "Processing of a natural hydroxyapatite powder: from powder optimization to porous bodies development," Journal of the European Ceramic Society, vol. 31, no. 14, pp. 2513-2518, 2011.

[6] O. Frank-Kamenetskaya, A. Kol'tsov, M. Kuz'mina, M. Zorina, and L. Poritskaya, "Ion substitutions and non-stoichiometry of carbonated apatite- $(\mathrm{CaOH})$ synthesised by precipitation and hydrothermal methods," Journal of Molecular Structure, vol. 992, no. 1-3, pp. 9-18, 2011.

[7] E. Landi, J. Uggeri, S. Sprio, A. Tampieri, and S. Guizzardi, "Human osteoblast behavior on as-synthesized $\mathrm{SiO}_{4}$ and B- $\mathrm{CO}_{3}$ co-substituted apatite," Journal of Biomedical Materials Research A, vol. 94, no. 1, pp. 59-70, 2010.

[8] Y. Doi, H. Iwanaga, T. Shibutani, Y. Moriwaki, and Y. Iwayama, "Osteoclastic responses to various calcium phosphates in cell cultures," Journal of Biomedical Materials Research, vol. 47, no. 3, pp. 424-433, 1999.

[9] Z. Zyman and M. Tkachenko, " $\mathrm{CO}_{2}$ gas-activated sintering of carbonated hydroxyapatites," Journal of the European Ceramic Society, vol. 31, no. 3, pp. 241-248, 2011.

[10] C. M. Botelho, R. A. Brooks, S. M. Best et al., "Human osteoblast response to silicon-substituted hydroxyapatite," Journal of Biomedical Materials Research A, vol. 79, no. 3, pp. 723730, 2006.

[11] A. E. Porter, C. M. Botelho, M. A. Lopes, J. D. Santos, S. M. Best, and W. Bonfield, "Ultrastructural comparison of dissolution and apatite precipitation on hydroxyapatite and silicon-substituted hydroxyapatite in vitro and in vivo," Journal of Biomedical Materials Research A, vol. 69, no. 4, pp. 670-679, 2004.

[12] E. Boanini, M. Gazzano, and A. Bigi, "Ionic substitutions in calcium phosphates synthesized at low temperature," Acta Biomaterialia, vol. 6, no. 6, pp. 1882-1894, 2010.

[13] S. Sprio, A. Tampieri, E. Landi et al., "Physico-chemical properties and solubility behaviour of multi-substituted hydroxyapatite powders containing silicon," Materials Science and Engineering C, vol. 28, no. 1, pp. 179-187, 2008.

[14] E. Landi, A. Tampieri, G. Celotti, L. Vichi, and M. Sandri, "Influence of synthesis and sintering parameters on the characteristics of carbonate apatite," Biomaterials, vol. 25, no. 10, pp. 1763-1770, 2004.

[15] M. Palard, E. Champion, and S. Foucaud, "Synthesis of silicated hydroxyapatite $\mathrm{Ca}_{10}\left(\mathrm{PO}_{4}\right)_{6-x}\left(\mathrm{SiO}_{4}\right)_{x}(\mathrm{OH})_{2-x}$," Journal of Solid State Chemistry, vol. 181, no. 8, pp. 1950-1960, 2008.

[16] E. Landi, A. Tampieri, M. Mattioli-Belmonte et al., "Biomimetic $\mathrm{Mg}$ - and $\mathrm{Mg}, \mathrm{CO}_{3}$-substituted hydroxyapatites: synthesis characterization and in vitro behaviour," Journal of the European Ceramic Society, vol. 26, no. 13, pp. 2593-2601, 2006.

[17] E. Landi, S. Sprio, M. Sandri, G. Celotti, and A. Tampieri, "Development of $\mathrm{Sr}$ and $\mathrm{CO}_{3}$ co-substituted hydroxyapatites for biomedical applications," Acta Biomaterialia, vol. 4, no. 3, pp. 656-663, 2008.
[18] N. Y. Mostafa, H. M. Hassan, and O. H. Abd Elkader, "Preparation and characterization of $\mathrm{Na}^{+}, \mathrm{SiO}_{4}^{4-}$, and $\mathrm{CO}_{3}^{2-}$ cosubstituted hydroxyapatite," Journal of the American Ceramic Society, vol. 94, no. 5, pp. 1584-1590, 2011.

[19] N. Y. Mostafa, H. M. Hassan, and F. H. Mohamed, "Sintering behavior and thermal stability of $\mathrm{Na}^{+}, \mathrm{SiO}_{4}^{4-}$, and $\mathrm{CO}_{3}^{2-}$ cosubstituted hydroxyapatites," Journal of Alloys and Compounds, vol. 479, no. 1-2, pp. 692-698, 2009.

[20] I. R. Gibson, S. M. Best, and W. Bonfield, "Chemical characterization of silicon-substituted hydroxyapatite," Journal of Biomedical Materials Research, vol. 44, pp. 422-428, 1999.

[21] L. T. Bang, K. Ishikawa, and R. Othman, "Effect of silicon and heat-treatment temperature on the morphology and mechanical properties of silicon-substituted hydroxyapatite," Ceramics International, vol. 37, no. 8, pp. 3637-3642, 2011.

[22] D. M. Ibrahim, A. A. Mostafa, and S. I. Korowash, "Chemical characterization of some substituted hydroxyapatites," Chemistry Central Journal, vol. 5, no. 1, article 74, 2011.

[23] J. L. Xu and K. A. Khor, "Chemical analysis of silica doped hydroxyapatite biomaterials consolidated by a spark plasma sintering method," Journal of Inorganic Biochemistry, vol. 101, no. 2, pp. 187-195, 2007.

[24] G. F. Kamst, J. Vasseur, C. Bonazzi, and J. J. Bimbenet, "New method for the measurement of the tensile strength of rice grains by using the diametral compression test," Journal of Food Engineering, vol. 40, no. 4, pp. 227-232, 1999.

[25] T. Kokubo and H. Takadama, "How useful is SBF in predicting in vivo bone bioactivity?” Biomaterials, vol. 27, no. 15, pp. 2907$2915,2006$.

[26] A. M. Pietak, J. W. Reid, M. J. Stott, and M. Sayer, "Silicon substitution in the calcium phosphate bioceramics," Biomaterials, vol. 28, no. 28, pp. 4023-4032, 2007.

[27] R. Z. LeGeros and J. P. LeGeros, "Calcim phosphate bioceramic: past, present and future," in Bioceramic, B. Ben-Nissan, D. Sher, and W. Walsh, Eds., vol. 15, pp. 3-10, Trans Tech Publications, Sydney, Australia, 2003.

[28] Y. Doi, T. Koda, N. Wakamatsu et al., "Influence of carbonate on sintering of apatites," Journal of Dental Research, vol. 72, no. 9, pp. 1279-1284, 1993.

[29] T. Huang, Y. Xiao, S. Wang et al., "Nanostructured Si, Mg, $\mathrm{CO}_{3}^{2-}$ substituted hydroxyapatite coatings deposited by liquid precursor plasma spraying: synthesis and characterization," Journal of Thermal Spray Technology, vol. 20, no. 4, pp. 829-836, 2011.

[30] A. Bianco, I. Cacciotti, M. Lombardi, and L. Montanaro, "Sisubstituted hydroxyapatite nanopowders: synthesis, thermal stability and sinterability," Materials Research Bulletin, vol. 44, no. 2, pp. 345-354, 2009.

[31] J. P. Lafon, E. Champion, and D. Bernache-Assollant, "Processing of AB-type carbonated hydroxyapatite $\mathrm{Ca}_{10-x}\left(\mathrm{PO}_{4}\right)_{6-x}\left(\mathrm{CO}_{3}\right)_{x}(\mathrm{OH})_{2-x-2 y}\left(\mathrm{CO}_{3}\right)_{y}$ ceramics with controlled composition," Journal of the European Ceramic Society, vol. 28, no. 1, pp. 139-147, 2008.

[32] M. Vallet-Regi and D. Arcos, "Silicon substituted hydroxyapatites. A method to upgrade calcium phosphate based implants," Journal of Materials Chemistry, vol. 15, no. 15, pp. 1509-1516, 2005.

[33] S. Kannan, S. I. Vieira, S. M. Olhero et al., "Synthesis, mechanical and biological characterization of ionic doped carbonated hydroxyapatite/ $\beta$-tricalcium phosphate mixtures," Acta Biomaterialia, vol. 7, no. 4, pp. 1835-1843, 2011. 
[34] J. W. Reid, L. Tuck, M. Sayer, K. Fargo, and J. A. Hendry, "Synthesis and characterization of single-phase silicon-substituted $\alpha$-tricalcium phosphate," Biomaterials, vol. 27, no. 15, pp. 29162925, 2006.

[35] X. L. Tang, X. F. Xiao, and R. F. Liu, "Structural characterization of silicon-substituted hydroxyapatite synthesized by a hydrothermal method," Materials Letters, vol. 59, no. 29-30, pp. 38413846, 2005.

[36] A. Aminian, M. Solati-Hashin, A. Samadikuchaksaraei et al., "Synthesis of silicon-substituted hydroxyapatite by a hydrothermal method with two different phosphorous sources," Ceramics International, vol. 37, no. 4, pp. 1219-1229, 2011.

[37] F. Balas, J. Pérez-Pariente, and M. Vallet-Regí, "In vitro bioactivity of silicon-substituted hydroxyapatites," Journal of Biomedical Materials Research A, vol. 66, no. 2, pp. 364-375, 2003.

[38] N. Douard, R. Detsch, R. Chotard-Ghodsnia, C. Damia, U. Deisinger, and E. Champion, "Processing, physico-chemical characterisation and in vitro evaluation of silicon containing $\beta$ tricalcium phosphate ceramics," Materials Science and Engineering C, vol. 31, no. 3, pp. 531-539, 2011.

[39] M. Veiderma, K. Tõnsuaadu, R. Knubovets, and M. Peld, "Impact of anionic substitutions on apatite structure and properties," Journal of Organometallic Chemistry, vol. 690, no. 10, pp. 2638-2643, 2005.

[40] I. R. Gibson and W. Bonfield, "Novel synthesis and characterization of an AB-type carbonate-substituted hydroxyapatite," Journal of Biomedical Materials Research, vol. 59, no. 4, pp. 697-708, 2002.

[41] I. R. Gibson, S. M. Best, and W. Bonfield, "Effect of silicon substitution on the sintering and microstructure of hydroxyapatite," Journal of the American Ceramic Society, vol. 85, no. 11, pp. 2771-2777, 2002.

[42] E. Landi, G. Celotti, G. Logroscino, and A. Tampieri, "Carbonated hydroxyapatite as bone substitute," Journal of the European Ceramic Society, vol. 23, no. 15, pp. 2931-2937, 2003.

[43] K. Rezwan, Q. Z. Chen, J. J. Blaker, and A. R. Boccaccini, "Biodegradable and bioactive porous polymer/inorganic composite scaffolds for bone tissue engineering," Biomaterials, vol. 27, no. 18, pp. 3413-3431, 2006.

[44] Y. W. Gu, K. A. Khor, and P. Cheang, "Bone-like apatite layer formation on hydroxyapatite prepared by spark plasma sintering (SPS)," Biomaterials, vol. 25, no. 18, pp. 4127-4134, 2004.

[45] M. A. Jyoti, V. V. Thai, Y. K. Min, B.-T. Lee, and H.-Y. Song, "In vitro bioactivity and biocompatibility of calcium phosphate cements using Hydroxy-propyl-methyl-Cellulose (HPMC)," Applied Surface Science, vol. 257, no. 5, pp. 1533-1539, 2010.

[46] H. Pan, X. Zhao, B. W. Darvell, and W. W. Lu, "Apatite-formation ability-predictor of "bioactivity"?" Acta Biomaterialia, vol. 6, no. 11, pp. 4181-4188, 2010.

[47] M. H. Fathi, A. Hanifi, and V. Mortazavi, "Preparation and bioactivity evaluation of bone-like hydroxyapatite nanopowder," Journal of Materials Processing Technology, vol. 202, no. 1-3, pp. 536-542, 2008.

[48] M. Kheradmandfard, M. H. Fathi, M. Ahangarian, and E. M. Zahrani, "In vitro bioactivity evaluation of magnesiumsubstituted fluorapatite nanopowders," Ceramics International, vol. 38, no. 1, pp. 169-175, 2012.

[49] R. Sun, M. Li, Y. Lu, and A. Wang, "Immersion behavior of hydroxyapatite (HA) powders before and after sintering," Materials Characterization, vol. 56, no. 3, pp. 250-254, 2006. 

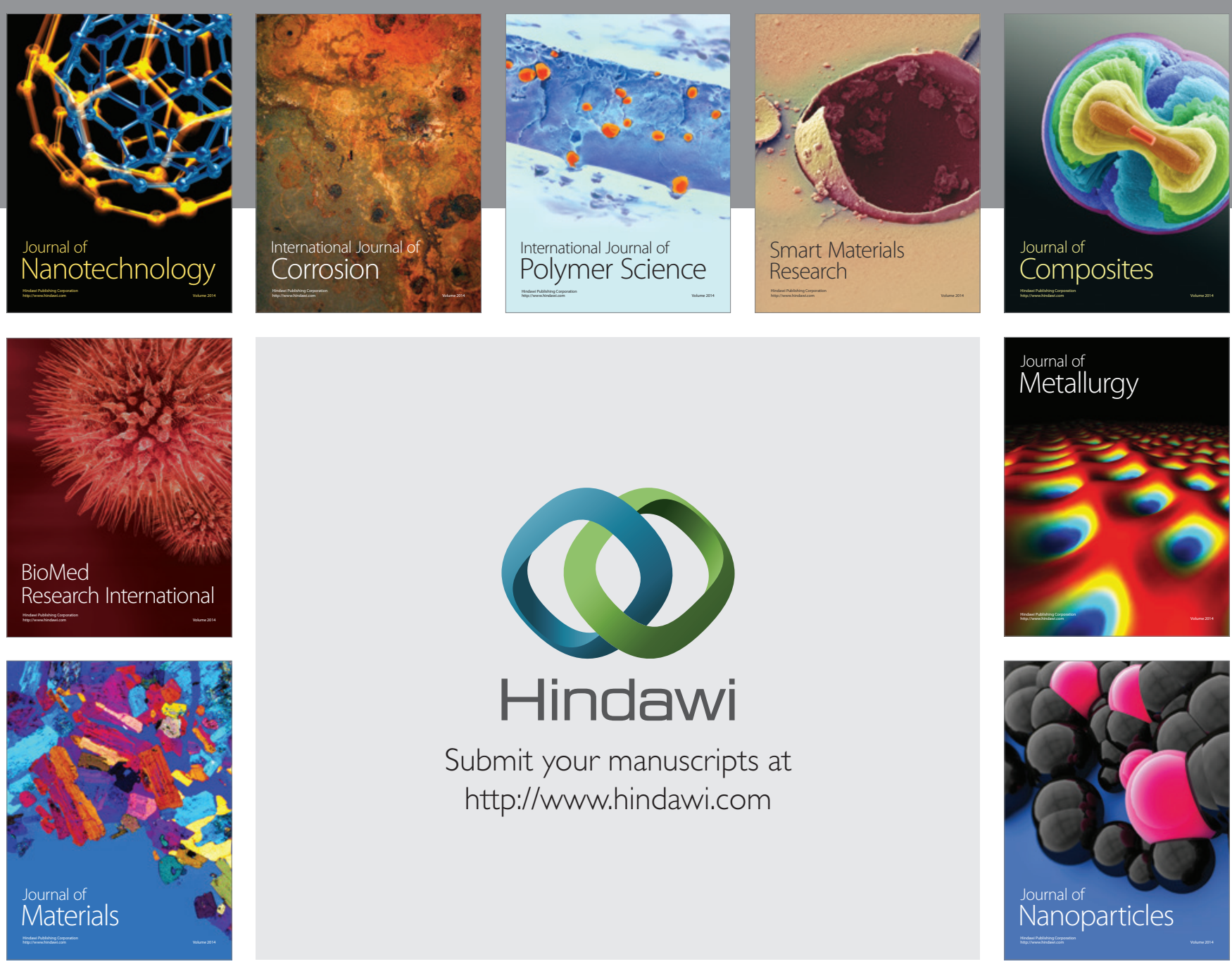

Submit your manuscripts at http://www.hindawi.com
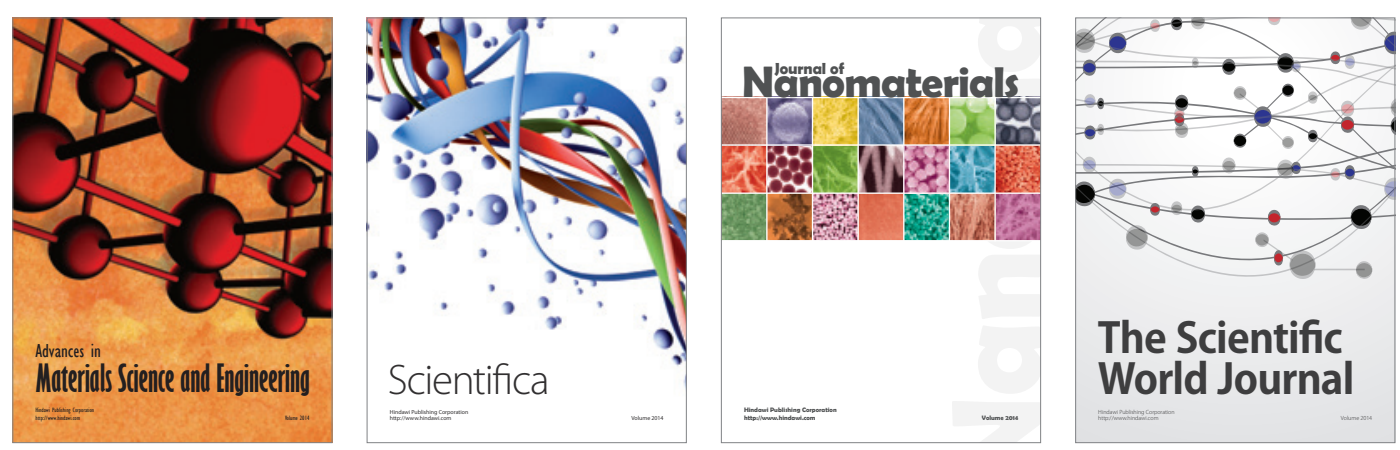

\section{The Scientific World Journal}
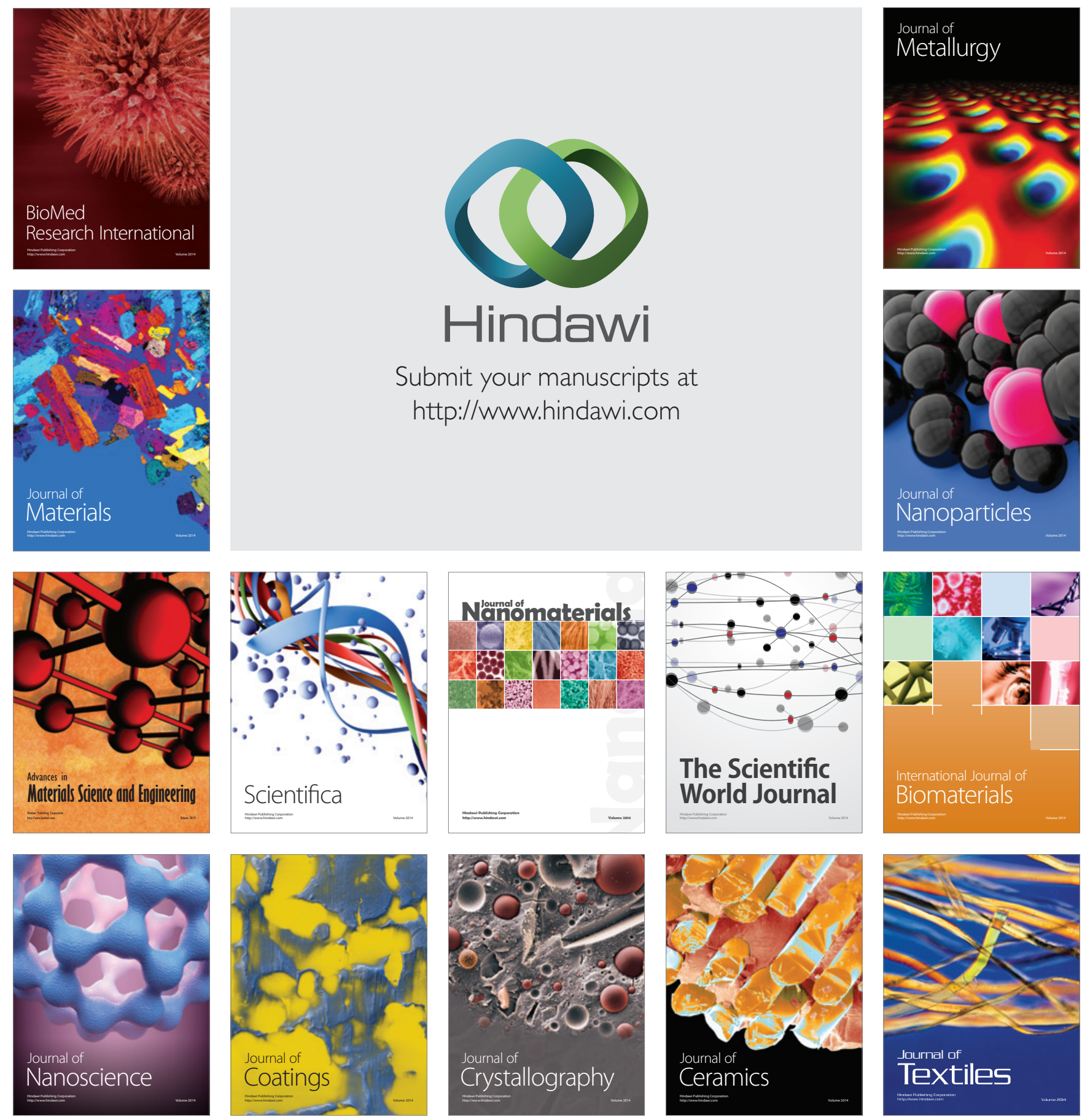